\title{
Pemeriksaan Dermatoglifik dan Penilaian Fenotip Sindrom Down Sebagai Uji Diagnostik Kariotip Aberasi Penuh Trisomi 21
}

\author{
Sjarif Hidajat*, Herry Garna*, Ponpon S Idjradinata*, Achmad Surjono**
}

Latar belakang: Sindrom Down (trisomi 21) terjadi karena aberasi numerik sebagai akibat kegagalan proses replikasi dan pemisahan sel anak (non-disjunction). Bentuk kariotip aberasi ini dapat berbentuk aberasi penuh dan dapat pula berbentuk mosaik, yang diduga mempunyai implikasi terhadap berat ringannya kelainan fenotip. Di samping penting untuk konseling genetik, penelaahan secara cepat di bangsal perinatologi juga diperlukan untuk asumsi sementara dalam menjawab pertanyaan keluarga pasien.

Tujuan: tujuan penelitian untuk mengetahui hubungan jenis kariotip dengan beratnya aberasi penuh terhadap beratnya fenotip sindrom Down.

Metoda: penelitian dilakukan pada 147 anak usia 0-5 tahun di Yayasan Suryakanti, RS Dr. Hasan Sadikin dan Yayasan Dian Grahita Jakarta. Penentuan fenotip sindrom Down dilakukan dengan penelaahan gejala utama dari kelainan tersebut. Dilakukan wawancara riwayat perinatal dan latar belakang keluarga serta pemeriksaan dermatoglifik, pemeriksaan antropometrik khusus dan pengambilan sampel darah untuk pemeriksaan kromosom dari kultur limfosit.

Hasil: didapatkan 146 anak mempunyai kelainan kariotip, yang ternyata semuanya trisomi 21, sedangkan seorang anak menunjukkan kariotip normal. Hasil analisis menunjukkan dermatoglifik, kelainan mata dan kelainan tangan dan kaki mempunyai hubungan yang signifikan dengan kariotip. Pada dermatoglifik abnormal 78,2\% mengarah ke kariotip aberasi penuh. Kelainan jantung bawaan, kelainan mata dan kelainan tangan dan kaki, terdapat masing-masing $82,4 \%, 77,7 \%$ dan $77,6 \%$. Secara bersama-sama yang memberikan nilai risiko tertinggi adalah kelainan gerak, kemudian kelainan mata dan dermatoglifik. Sebanyak 47 anak (32\%) menunjukkan kariotip mosaik dan 99 anak (68\%) jenis aberasi penuh. Diperoleh besarnya risiko terjadinya kariotip aberasi penuh adalah 9,5 kali pada keempat variabel fenotip abnormal dibandingkan dengan subjek tanpa gangguan fenotip dan dermatoglifik. Kelainan dermatoglifik, kelainan mata dan kelainan tangan serta kaki secara bermakna menunjukkan adanya hubungan antara satu variabel dengan lainnya, makin rendah persentase sel normal pada kariotip aberasi penuh, makin abnormal keadaan dermatoglifik dan fenotip organ tubuh tersebut.

Kesimpulan: pasien kelainan aberasi kromosom numerik, khususnya trisomi 21, mempunyai kelainan gabungan dermatoglifik serta kelainan organ tertentu dalam derajat yang maksimal, dan cenderung menunjukkan kariotip jenis aberasi penuh.

Kata kunci: Kariotip mosaik, kariotip aberasi penuh, dermatoglifik, fenotip, KJB

\footnotetext{
Alamat Korespondensi:

Dr. Sjarif Hidayat, Sp.A. Bagian/SMF Ilmu Kesehatan Anak FKUP/RSUP dr. Hasan Sadikin,

Bandung. Jl. Pasteur No. 38 Telp./Fax. 2034426-203595 Bandung 40161.

* Bagian Ilmu Kesehatan Anak Fakultas kedokteran Universitas Padjadjaran, Bandung.

** Bagian Ilmu Kesehatan Anak Fakultas Kedokteran Universitas Gajah Mada. Yogyakarta.
} 
S indrom Down (trisomi 21) merupakan kelainan kromosom yang paling sering dijumpai pada anak dan merupakan penyebab genetik tersering dari retardasi mental., ${ }^{1,2}$ Bila dibandingkan dengan sindrom Edward (trisomi 18) dan sindrom Patau (trisomi 13) angka kejadiannya adalah sebagai berikut; 1 dari 660 kelahiran (trisomi 21); 3 dari 1.000 kelahiran (trisomi 18) dan 1 dari 5.000 kelahiran (trisomi 13). ${ }^{3}$ Pada hakekatnya telah diketahui bahwa terdapat kecenderungan dismorfogenesis yang konsisten dalam pembentukan organ yang mengalami kelainan tersebut. ${ }^{3,4}$

Kelainan fenotip pasien kelainan aberasi kromosom numerik pada umumnya menunjukkan gejala sebagai berikut, ${ }^{3}$ pertumbuhan dan perkembangan kurang, kelainan kepala dan wajah, telinga, rongga mulut, bentuk tangan dan kaki, jantung, mata, pendengaran, dan sistem reproduksi, serta tubuh yang pendek (short stature)(Tabel 1).

Tabel 1. Gambaran Dismorfi Beberapa Organ Tubuh Trisomi 21, 18, 13, $\mathrm{X}$ dan $\mathrm{Y}^{3}$

\begin{tabular}{llllll}
\hline \multirow{2}{*}{ ismorfi organ tubuh } & \multicolumn{7}{c}{ Trisomi } \\
\cline { 2 - 6 } & 21 & 18 & 13 & $\mathrm{X}$ & $\mathrm{Y}$ \\
\hline Kepala & + & + & + & - & - \\
Telinga & + & + & + & + & - \\
Mulut & - & + & + & + & - \\
Mata & + & + & + & - & - \\
Jari & + & + & + & - & - \\
Dermatoglifik & + & + & + & - & - \\
Leher & + & - & - & - & - \\
Genitalia (laki-laki) & + & + & + & + & + \\
\hline
\end{tabular}

Terlihat bahwa kelainan dismorfik yang konsisten pada trisomi 21, 18 dan 13 terjadi pada kepala, telinga, mata, jari, dermatoglifik dan genital laki-laki. Selain itu dermatoglifik, yaitu konfigurasi lengkung/alur kulit pada jari, telapak tangan dan kaki, juga menunjukkan pola yang abnormal pada kelainan bawaan jenis kromosomal. $5,6,7,8$

Selama bertahun-tahun dermatoglifik telah diterima sebagai alat bantu yang berguna untuk membedakan kembar monozigot dan kembar dizigot, sebelum akhir-akhir ini digunakan untuk membantu diagnosis sindrom Down. Dengan berkembangnya pengetahuan sitogenetik mahluk hidup dan penelitian aberasi kromosom pada manusia maka peran dermatoglifik dalam kedokteran klinis menjadi lebih penting. Pemeriksaan pola kulit memberikan nilai pada kasus sindrom Down dengan diagnosis klinis meragukan. Berbagai kombinasi dan tipe pola kulit yang ditemukan pada jari, telapak tangan dan kaki, membuktikan bahwa formasi alur kulit dapat ditentukan oleh bermacam-macam gen yang tersebar pada beberapa kromosom. Pada mongolisme timbulnya ekstra kromosom dengan sejumlah besar gen menyebabkan perkembangan yang abnormal dari beberapa sistem organ termasuk alur kulit., ${ }^{5,9}$

Terdapat kecenderungan adanya fenotip yang lebih baik, dalam segi fisik maupun mental, pada individu yang mengalami kelainan kromosom mosaik dibandingkan dengan yang mengalami kelainan kromosom penuh, walaupun ini baru diamati pada trisomi 21 .

Adanya fenomena mosaik ini mengandung arti yang besar dari segi klinis (fenotip) karena cenderung menunjukkan pola lebih ringan dibandingkan dengan trisomi 21 penuh. ${ }^{3,10,11}$

Didapatkan fakta bahwa skor IQ kasus trisomi 21 mosaik ternyata 10-30 lebih tinggi dibandingkan dengan bentuk trisomi 21 penuh. ${ }^{3}$ Fenomena mosaik ini diduga mempunyai tempat tersendiri dalam nasihat genetik, terutama dalam hal pemberian nasihat tentang prognosis pasien kelainan bawaan jenis kromosomal. Telah lama diketahui bahwa pemeriksaan kromosom merupakan suatu prosedur yang mahal, memakan waktu lama dan memerlukan keahlian yang sangat tinggi. ${ }^{12}$

Telah didapatkan beberapa laporan tentang berbagai variasi indeks diagnostik mengenai sindrom Down (trisomi 21). . $13,14^{2}$ Dengan pemeriksaan dermatoglifik dan dismorfik beberapa organ tubuh pasien kelainan bawaan kromosom trisomi 21diharapkan dapat menunjukkan faktor risiko ke arah kromosom aberasi penuh yang akan diambil pegangan sebagai penilaian prognosis.

Tujuan penelitian ini adalah untuk menilai besarnya peranan gabungan dermatoglifik serta kelainan dismorfi beberapa organ tubuh penderita sindrom Down sebagai faktor risiko kariotip jenis aberasi penuh.

\section{Metoda}

Penelitian ini merupakan penelitian genetika medik, analitik yang dilakukan secara cross-sectional terhadap anak dengan kelainan fenotip trisomi 21. Subjek 
diperiksa dermatoglifik, pengukuran dan pengamatan secara cermat terhadap organ tubuh tertentu untuk mendapatkan hasil pemeriksaan dismorfik beberapa organ tubuh, analisis kromosom kultur limfosit (kariotip), wawancara terhadap orangtua/wali subjek, pemberian nasihat genetik disertai wawancara secara mendalam (indepth interview) terhadap beberapa kasus dan pengolahan data disertai analisis statistik.

Subjek penelitian diperoleh dari daftar pasien kelainan bawaan dengan gambaran fenotip trisomi 21 Pusat Pengembangan Potensi Anak Yayasan Suryakanti Bandung melalui KIDS (Keluarga Insan Down Syndrome), Klinik Tumbuh Kembang RSUP Dr. Hasan Sadikin Bandung, dan Yayasan Dian Grahita Jakarta melalui Perkumpulan ISDI (Ikatan Sindrom Down Indonesia). Terhadap subyek tersebut dilakukan kunjungan rumah untuk mendapatkan informed consent. Pemeriksaan fisis dan dermatoglifik dilakukan di Bagian Ilmu Kesehatan Anak FKUP/RSUP Dr. Hasan Sadikin Bandung, Yayasan Suryakanti Bandung, dan Yayasan Dian Grahita di Jakarta.

Pengambilan darah untuk analisis kromosom dilakukan oleh petugas laboratorium dan dikirimkan pada hari yang sama ke Laboratorium Biotek Universitas Padjadjaran/PAU Hayati ITB. Hasil penelaahan dermatoglifik konfirmasi oleh Bagian Biomedik Fakultas Kedokteran Universitas Padjadjaran, Bandung.

\section{Hasil}

Didapat 196 anak yang turut dalam penelitian ini dengan kelainan kariotip trisomi 21. Mosaikism adalah fenomena tercampurnya kromosom yang mengalami aberasi dengan kromosom normal, dengan rentang batasan di antara $40-80 \% .{ }^{15}$ Pemeriksaan kromosom melalui kultur limfosit diperoleh hasil kariotip dengan mosaik 47 anak (32\%), dan termasuk kariotip aberasi penuh terdapat pada 99 anak (68\%). Hasil pemeriksaan kromosom yang paling utama ditemukan adalah tipe $46 \mathrm{XX} / \mathrm{XY}(33 \%)$ dan tipe $47 \mathrm{XX} / \mathrm{XY}$ $(41 \%)$. Sebagian besar hasil analisis kromosom menunjukkan bentuk aberasi penuh (68\%) yang sesuai dengan penelitian sebelumnya, walaupun angkanya lebih rendah. ${ }^{3,16,17,18}$ (Gambar 1). Terlihat bahwa jenis kelamin laki-laki dan perempuan tidak berbeda baik pada kelompok mosaik maupun trisomi 21 penuh.

Tabel 2 menunjukkan hasil pemeriksaan dermatoglifik, kelainan jantung bawaan, mata, tangan dan

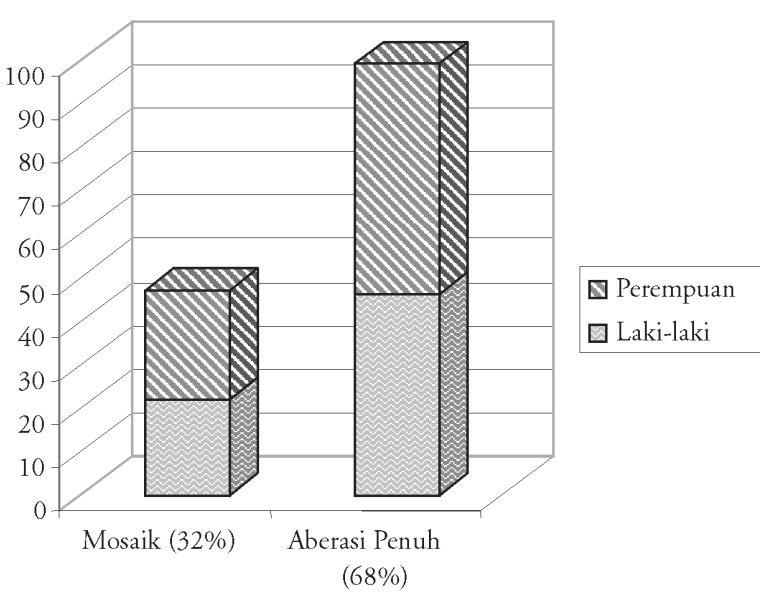

Gambar 1. Grafik Hasil Analisis Kromosom pada Anak Trisomi 21

kaki pada subjek dengan kariotip aberasi penuh dan aberasi mosaik. Dari keempat variabel tersebut, tiga variabel yaitu dermatoglifik, kelainan mata dan kelainan tangan dan kaki berhubungan bermakna dengan kejadian kariotip, sedangkan kelainan jantung bawaan tidak bermakna ( $\mathrm{p}=0,172)$.

Berdasarkan Tabel 2, nampak bahwa adanya kelainan pada mata atau kelainan pada tangan dan kaki mempunyai risiko untuk terjadinya kariotip aberasi penuh sebesar 1,6 kali dibandingkan dengan yang normal. Sedangkan adanya gangguan dermatoglifik mempunyai risiko untuk terjadinya aberasi penuh adalah sebesar 1,5 kali dibandingkan dengan pasien yang mempunyai dermatoglifik normal.

Berdasarkan penggabungan beberapa kelainan (Tabel 3), terlihat kasus kariotip aberasi penuh terbanyak adalah kombinasi dermatoglifik, kelainan mata, tangan dan kaki (29 kasus), sedangkan gabungan antara kelainan mata, tangan dan kaki didapatkan 18 kasus, serta gabungan dermatoglifik dan kelainan tangan dan kaki terdapat 16 kasus.

Untuk kasus dengan kariotip mosaik didapatkan 8 kasus dengan kelainan tunggal anggota gerak, 7 kasus kelainan mata dan 7 kasus tanpa kelainan fenotip. Sedangkan untuk penggabungan didapatkan tiga macam, yaitu dermatoglifik dan kelainan tangan dan kaki (5 kasus), dermatoglifik dan kelainan mata (5 kasus), serta kelainan mata, tangan dan kaki (5 kasus). Di samping itu untuk gambaran mosaik didapatkan juga 7 kasus tanpa kelainan fenotip.

Selanjutnya untuk mengetahui pengaruh bersamasama dari keempat variabel fenotip dilakukan analisis 
Tabel 2. Hasil Pemeriksaan Fenotip Sindrom Down Dihubungkan dengan Jenis Kariotip

\begin{tabular}{|c|c|c|c|c|c|}
\hline \multirow[b]{2}{*}{ Pemeriksaan fenotip } & \multicolumn{2}{|c|}{ Kariotip } & \multirow{2}{*}{$\begin{array}{c}\text { Risiko } \\
\text { kariotip } \\
\text { aberasi penuh } \\
(\%)\end{array}$} & \multirow{2}{*}{$\begin{array}{l}\text { Perbandingan } \\
\text { risiko kariotip } \\
\text { aberasi penuh } \\
(95 \% \text { C.I })\end{array}$} & \multirow[b]{2}{*}{$\begin{array}{c}\text { Nilai } \\
\mathrm{p}\end{array}$} \\
\hline & $\begin{array}{l}\text { Aberasi } \\
\text { penuh } \\
(\mathrm{n}=99)\end{array}$ & $\begin{array}{l}\text { Mosaik } \\
(\mathrm{n}=47)\end{array}$ & & & \\
\hline \multicolumn{6}{|l|}{ 1. Dermatoglifik } \\
\hline abnorsmal & 68 & 19 & 78,2 & 1,5 & $<0,01^{*}$ \\
\hline normal & 31 & 28 & 52,5 & $(1,1-1,9)$ & \\
\hline \multicolumn{6}{|l|}{ 2. Kelainan jantung } \\
\hline abnormal & 14 & 3 & 82,4 & 1,3 & 0,172 \\
\hline normal & 85 & 44 & 65,9 & $(0,9-1,6)$ & \\
\hline \multicolumn{6}{|l|}{ 3. Kelainan mata } \\
\hline abnormal & 73 & 21 & 77,7 & 1,6 & $<0,001^{*}$ \\
\hline normal & 26 & 26 & 50 & $(1,2-2,1)$ & \\
\hline \multicolumn{6}{|c|}{$\begin{array}{l}\text { 4. Kelainan tangan dan } \\
\text { kaki }\end{array}$} \\
\hline abnormal & 76 & 22 & 77,6 & 1,6 & $<0,001^{*}$ \\
\hline normal & 23 & 25 & 47,9 & $(1,2-2,2)$ & \\
\hline
\end{tabular}

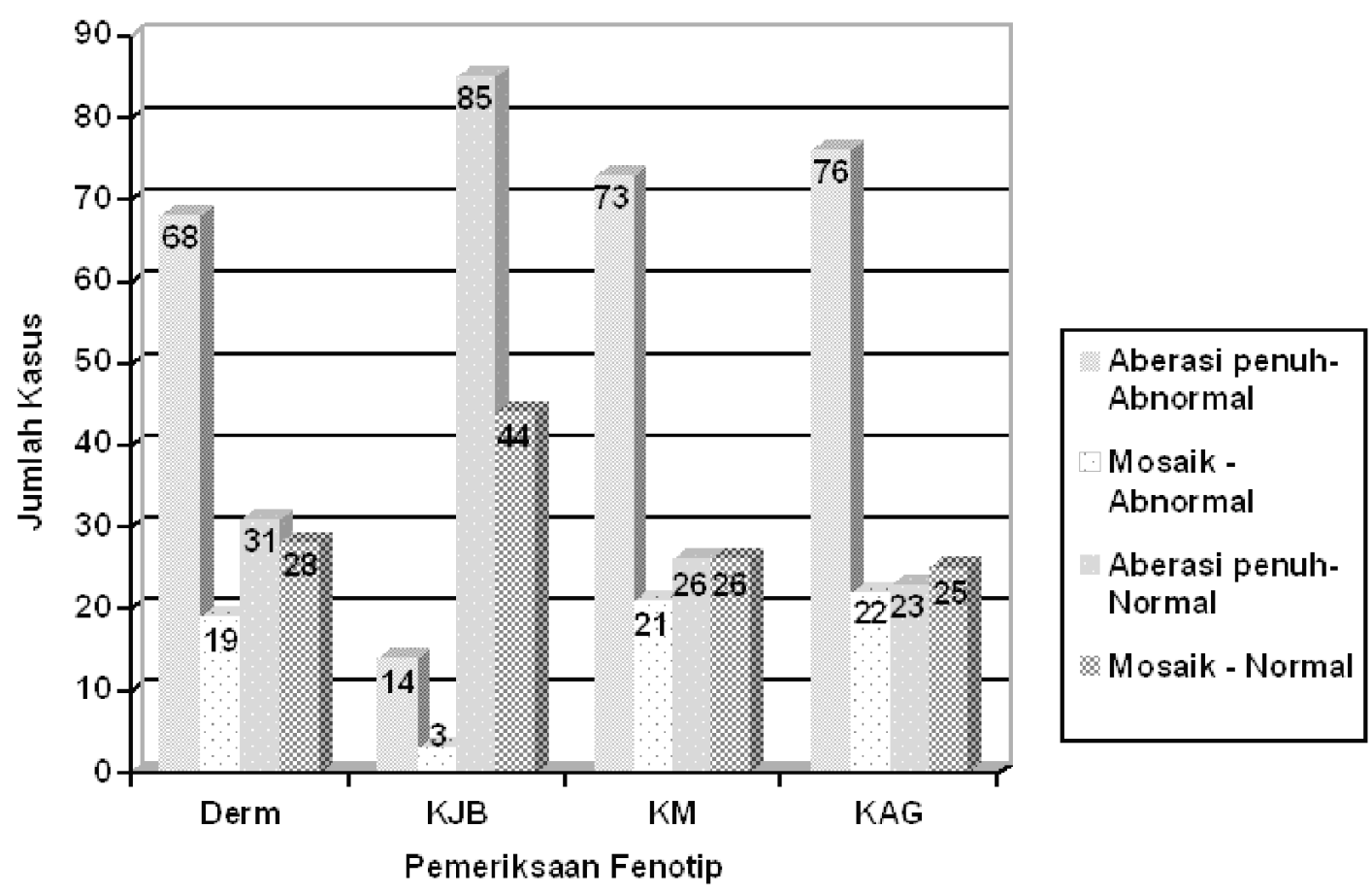

Gambar 2. Grafik Hasil Pemeriksaan Fenotip Sindrom Down Dihubungkan dengan Jenis Kariotip 
Sari Pediatri, Vol. 7, No. 2, September 2005

Tabel 3. Berbagai Kelainan pada Penderita Sindrom Down

\begin{tabular}{|c|c|c|c|c|c|c|c|c|}
\hline \multirow[b]{2}{*}{ Gabungan } & \multicolumn{4}{|c|}{ Kelainan } & \multicolumn{2}{|c|}{ Jumlah kasus } & \multicolumn{2}{|c|}{ Persen (\%) } \\
\hline & $\mathrm{X}_{1}$ & $\mathrm{X}_{2}$ & $\mathrm{X}_{3}$ & $\mathrm{X}_{4}$ & penuh & mosaik & penuh & mosaik \\
\hline 1 & 1 & 1 & 1 & 1 & 4 & 0 & 4 & 0 \\
\hline 2 & 1 & 1 & 1 & 0 & 4 & 0 & 4 & 0 \\
\hline 3 & 1 & 1 & 0 & 1 & 2 & 0 & 2 & 0 \\
\hline 4 & 1 & 0 & 1 & 1 & 29 & 3 & 30 & 6 \\
\hline 5 & 0 & 1 & 1 & 1 & 3 & 1 & 3 & 2 \\
\hline 6 & 1 & 1 & 0 & 0 & 1 & 2 & 1 & 4 \\
\hline 7 & 1 & 0 & 0 & 1 & 16 & 5 & 16 & 11 \\
\hline 8 & 0 & 0 & 1 & 1 & 18 & 5 & 18 & 11 \\
\hline 9 & 0 & 1 & 1 & 0 & 0 & 0 & 0 & 0 \\
\hline 10 & 1 & 0 & 1 & 0 & 9 & 5 & 9 & 11 \\
\hline 11 & 0 & 1 & 0 & 1 & 0 & 0 & 0 & 0 \\
\hline 12 & 1 & 0 & 0 & 0 & 3 & 4 & 3 & 9 \\
\hline 13 & 0 & 1 & 0 & 0 & 0 & 0 & 0 & 0 \\
\hline 14 & 0 & 0 & 1 & 0 & 6 & 7 & 6 & 15 \\
\hline 15 & 0 & 0 & 0 & 1 & 4 & 8 & 4 & 17 \\
\hline 16 & 0 & 0 & 0 & 0 & 0 & 7 & 0 & 15 \\
\hline Jumlah & & & & & 99 & 47 & 100 & 100 \\
\hline $\begin{array}{l}\text { Keterangan: } \\
\mathrm{X}_{1}=\text { dermatogl } \\
\mathrm{X}_{2}=\text { kelainan } \mathrm{ja} \\
\mathrm{X}_{3}=\text { kelainan } \mathrm{m} \\
\mathrm{X}_{4}=\text { kelainan ta }\end{array}$ & & vaan & & & & & & \\
\hline
\end{tabular}

regresi logistik multipel. Hasilnya seperti tertera pada Tabel 4.

Pada Tabel 4 tampak bahwa variabel yang paling erat hubungannya dengan kariotip adalah $\mathrm{X}_{4}$ (kelainan tangan dan kaki) dengan besarnya Odds Ratio 5,55, diikuti dengan kelainan mata (Odd Ratio $=4,97)$ dan dermatoglifik dengan Odds Ratio = 4,59.

Dari keempat kelainan fenotip jika digabungkan diperoleh 7 kasus tanpa kelainan fenotip dan dermatoglifik, 32 kasus dengan satu kelainan, 61 kasus dengan dua kelainan, 42 kasus dengan tiga kelainan dan 4 kasus dengan empat kelainan. Gabungan kelainan ini dihubungkan dengan jenis aberasi, tertera pada Tabel 5.

Dari Tabel 5 tampak bahwa pasien sindrom down tanpa kelainan dermatoglifik dan fenotip mengarah ke jenis aberasi mosaik, sedangkan pasien dengan empat kelainan (dermatoglifik, kelainan jantung

Tabel 4. Hasil Analisis Regresi Logistik Multipel Hubungan Antar Variabel Fenotip dengan Terjadinya Kariotip Penuh

\begin{tabular}{ccccccccc}
\hline Variabel & B & $\begin{array}{c}\text { S.E. } \\
\text { (B) }\end{array}$ & Wald & df & Sig & $\begin{array}{c}\text { Exp } \\
\text { (B) }\end{array}$ & \multicolumn{2}{c}{ 95\% C.I. for EXP (B) } \\
\hline $\mathrm{X}_{1}$ & 1,52 & 0,43 & 12,32 & 1 & 0,00 & 4,59 & 1,96 & 10,73 \\
$\mathrm{X}_{2}$ & 0,77 & 0,71 & 1,18 & 1 & 0,28 & 2,17 & 0,54 & 8,74 \\
$\mathrm{X}_{3}$ & 1,60 & 0,44 & 13,48 & 1 & 0,00 & 4,97 & 2,11 & 11,68 \\
$\mathrm{X}_{4}$ & 1,71 & 0,45 & 14,37 & 1 & 0,00 & 5,55 & 2,29 & 13,45 \\
Constant & $-2,17$ & 0,56 & 15,09 & 1 & 0,00 & 0,12 & & \\
\hline
\end{tabular}

\footnotetext{
Keterangan: $\mathrm{B}=$ koefisien regresi

S.E. $(B)=$ standar error koefisien regresi

Wald = statistik Wald [B / S.E.(B)]

$\mathrm{df} \quad=$ degrees of freedom

Sig = signifikansi

Exp $(\mathrm{B})=$ besarnya odds ratio (taksiran risiko relatif)

C.I. $=$ confidence interval

Akurasi : $76,7 \%$
} 
Tabel 5. Hubungan antara Gabungan Dermatoglifik dan Fenotip dengan Jenis Aberasi Trisomi 21

\begin{tabular}{ccccc}
\hline $\begin{array}{c}\text { Gabungan } \\
\text { kelainan }\end{array}$ & $\mathrm{n}$ & \multicolumn{2}{c}{$\begin{array}{c}\text { Aberasi } \\
\text { penuh mosaik }\end{array}$} & $\begin{array}{c}\mathrm{RR} \\
(95 \% \mathrm{CI})\end{array}$ \\
\hline 0 & 7 & 0 & 7 & - \\
1 & 32 & 13 & 19 & 1,0 \\
2 & 61 & 44 & 17 & $1,78(1,14-2,78)$ \\
3 & 42 & 38 & 4 & $2,23(1,45-3,42)$ \\
4 & 4 & 4 & 0 & - \\
\hline
\end{tabular}

$\mathrm{X}^{2}=37,88 ; \mathrm{p}<0,001$

bawaan, kelainan mata serta kelainan tangan dan kaki) mengarah ke jenis aberasi penuh. Untuk aberasi penuh dengan satu kelainan terdapat 13 kasus (41\%), dua kelainan 44 kasus (72\%) dan tiga kelainan 38 kasus (90\%). Dari hasil analisis tersebut terlihat bahwa semakin banyak jumlah kelainan, besarnya persentase aberasi penuh semakin tinggi.

Tabel 6 memperlihatkan akurasi yang paling tinggi adalah hasil pemeriksaan fenotip kelainan tangan dan kaki diikuti dengan kelainan mata dan dermatoglifik, sedangkan untuk kelainan jantung bawaan memberikan akurasi yang paling rendah.

\section{Diskusi}

Dermatoglifik pada seorang anak yang mengalami trisomi 21 berhubungan dengan bentuk kariotip khususnya bentuk mosaik dan aberasi penuh. Keadaan ini mengandung arti bahwa perhitungan skor dermatoglifik dapat dipakai sebagai salah satu uji diagnostik dan derajat kariotip mosaik hingga penuh. Hal ini terbukti secara tidak langsung dapat memperkirakan prognosis. Kelainan mata (occular dysmorphic) pada pasien trisomi 21 berupa salah satu atau lebih dari gejala upslanted palbebral fissure, epikantus, nistagmus, strabismus dan brushfield iris, menyokong adanya prediksi terhadap jenis kariotip pasien. Sedangkan berat ringannya occular dysmorphic ini, sejalan dengan jumlah kelainan yang didapat dan mempengaruhi derajat kariotip. Kelainan jantung bawaan (KJB) pada seorang anak trisomi 21 pada penelitian ini ternyata tidak semuanya menunjukkan kearah kariotip aberasi penuh. Karena keterbatasan jumlah subjek yang mengalami $\mathrm{KJB}$, maka peran KJB terhadap jenis kariotip memerlukan penelitian lebih lanjut. Sedangkan perannya sebagai gabungan dengan fenotip lain juga tidak terbukti menunjukkan kelainan kariotip aberasi penuh. Kelainan tangan dan kaki pada trisomi 21 ternyata merupakan variabel yang paling erat hubungannya dengan jenis kariotip bila dibandingkan dengan dermatoglifik dan kelainan mata. Terjadinya aberasi penuh trisomi 21 berdasarkan analisis regresi logistik multipel adalah sebesar 5,55 kali dibandingkan dengan tanpa kelainan tangan dan kaki. Namun, dalam menentukan jenis kariotip variabel ini memerlukan penggabungan dengan kelainan mata dan dermatoglifik. Banyaknya sel normal yang ditemukan pada kariotip aberasi mosaik maupun aberasi penuh sesuai dengan berat ringannya kelainan dermatoglifik dan fenotip organ mata dan tangan serta kaki.

Dalam menghadapi pasien yang mempunyai kelainan bawaan secara klinis mempunyai fenotip sindrom Down, dapat diperkirakan bahwa anak tersebut mempunyai kariotip jenis aberasi penuh apabila terutama didapatkan kelainan tunggal pada tangan dan kaki.

Hasil fenotip positif abnormal menunjukkan bahwa adanya kelainan dermatoglifik 1,7 kali kemungkinan ke arah kariotip aberasi penuh dibandingkan dengan kariotip aberasi mosaik dan adanya hasil pemeriksaan fenotip yang normal menunjukkan kemungkinan 0,5 kali terdapat pada kariotip aberasi penuh dibandingkan dengan pada kariotip aberasi mosaik.

Tabel 6. Sensitivitas, Spesifisitas, Akurasi dan Likelihood Ratio Keempat Pemeriksaan Fenotip

\begin{tabular}{lccccc}
\hline \multicolumn{1}{c}{$\begin{array}{c}\text { Pemeriksaan } \\
\text { Fenotip }\end{array}$} & $\begin{array}{c}\text { Sensitivitas } \\
(\%)\end{array}$ & $\begin{array}{c}\text { Spesifisitas } \\
(\%)\end{array}$ & $\begin{array}{c}\text { Akurasi } \\
(\%)\end{array}$ & LR (+) & LR (-) \\
\hline Dermatoglifik & 68,7 & 59,6 & 65,8 & 1,7 & 0,5 \\
Kelainan jantung bawaan & 14,1 & 93,6 & 39,7 & 2,2 & 0,9 \\
Kelainan mata & 73,7 & 55,3 & 67,8 & 1,7 & 0,5 \\
Kelainan tangan dan kaki & 76,8 & 53,2 & 69,2 & 1,6 & 0,4 \\
\hline
\end{tabular}


Adanya kelainan jantung bawaan pada sindrom Down mempunyai kemungkinan 2,2 kali terdapat pada kariotip aberasi penuh diandingkan dengan pada kariotip aberasi mosaik dan tidak adanya kelainan jantung bawaan ini menunjukkan kemungkinan 0,9 kali (hampir sama) terdapat pada keriotip jenis aberasi penuh dibandingkan dengan kariotip aberasi mosaik. Adanya nilai akurasi yang rendah dan spesifisitas yang tinggi dengan sensitivitas yang rendah menunjukkan bahwa kelainan jantung bawaan ini tidak begitu nyata untuk dipergunakan sebagai variabel diagnostik.

Kelainan pada organ mata sindrom Down menunjukkan 1,7 kali kemungkinan terjadi pada kariotip aberasi penuh dibandingkan dengan kariotip aberasi mosaik, dan tidak didapatkannya kelainan pada organ mata tersebut kemungkinan 0,5 kali terdapat pada pasien dengan kariotip aberasi penuh dibandingkan dengan pada aberasi mosaik. Adanya kelainan pada tangan dan kaki kemungkinan 1,6 kali terdapat pada pasien dengan jenis kariotip aberasi penuh dibandingkan dengan jenis kariotip aberasi mosaik, dan tidak adanya kelainan pada organ tersebut menunjukkan kemungkinan 0,4 kali terdapat pada kariotip aberasi penuh dibandingkan dengan pada kariotip aberasi mosaik. Penggabungan kelainan fenotip ternyata menunjukkan adanya hasil yang konsisten bahwa makin banyak kelainan fenotip maka risiko terjadinya kariotip aberasi penuh lebih besar dibandingkan dengan kariotip aberasi mosaik.

Untuk melakukan penilaian prognosis pasien trisomi 21 di ruang persalinan sebelum dilaksanakannya pemeriksaan (analisis) kromosom, dapat dilakukan pemeriksaan dermatoglifik, penilaian adanya deformitas pada organ kepala, mata dan ekstremitas, untuk membuat prediksi tentang jenis kariotip pasien. Adanya prediksi ke arah kariotip mosaik tentu akan mendorong orangtua untuk melakukan intervensi secara lebih cermat dan terarah agar potensi anak dapat diberdayakan secara lebih optimal. Sebaliknya adanya prediksi ke arah kariotip jenis aberasi penuh akan mempersiapkan orangtua untuk menerima prognosis yang kurang baik ini dengan berbagai upaya fisik maupun psikologis terhadap segenap keluarga untuk menerima pasien dan mengusahakan agar mampu melatih secara maksimal.

Peran kelainan jantung bawaan sebagai prediktor tunggal maupun prediktor gabungan dalam uji diagnostik memerlukan penelitian lebih lanjut dengan jumlah sampel yang lebih besar sehingga variabel KJB diperoleh dengan jumlah yang cukup. Selain itu perlu dipertanyakan apakah kelainan jantung bawaan tidak berperan terhadap penentuan jenis kariotip aberasi penuh atau aberasi mosaik.

Adanya "kemunduran" ilmiah akibat dilakukannya penggunaan alat diagnostik pengganti analisis kromosom yang memiliki kendala finansial di saat negara belum mencapai taraf ekonomi yang tinggi tentu perlu diimbangi dengan dilaksanakannya penelitian yang menyangkut masalah analisis mosaik tersebut dengan deteksi aneuploidi praktis melalui quantitative polymerase chain reaction. ${ }^{19,20}$

\section{Daftar Pustaka}

1. Antonarakis SE. The Down syndrome collaborative group. Parental origin of the extrachromosome in trisomy 21 as indicated by analysis of DNA polymorphisms. N Engl J Med 1991;321:872-6.

2. Ahmed MN, DeLong GR, Qumsiyeh MB. Postnatal development delay and chromosomal abnormalities. Clin Pediatr 2000;39:233-5.

3. Jones KL. Morphogenesis and dysmorphogenesis. Smith's recognizable pattern of human malformation, edisi ke-5. Philadelphia: WB Saunders, 1997; 695-704.

4. Aase JM. Diagnostic dismorphology. New York: Plenum Medical Book Co, 1990; 15-20, 230-1, 259-69, 271-98.

5. Uchida IA, Soltan HC. Evaluation of dermatoglyphics in medical genetica. Pediatr Clin North Am 1963; 10:409-22.

6. Rodewald A, Zankl M, Zankl H, Zang KD. Dermatoglyphs in carriers of a balanced 15;21 translocation. J Med Genet 1980;17:301-5.

7. Jones MC. Unilateral epicanthal fold; Diagnostic significance. J Pediatr 1986; 108:702-4.

8. Nova JJ, Clarke P, Frazer FC. Med genetic principles and practise, edisi ke-3. Philadelphia: Lea and Febiger, 1989; 278-84.

9. Schaumann B, Alter M. Dermatoglyphics in medical disorders. New York: Springer-Verlag, 1976; 65-90.

10. Janet MS, David KM, Eva S. Genetics and dysmorphology. Current pediatrics diagnosis and treatment, edisi ke-12. Apleton \& Lange, 1995; 947-87.

11. Aase JM. Dysmorphologic diagnosis for the pediatric practitioner. Pediatr Clin North Am 1992;39:135-55.

12. Adinolfi M, Pertl B, Sherlock J. Rapid detection of aneuploidies by microsatellite and the quantitative fluorescent polymerase chain reaction. Prenat Diagn 1997; 
17:1299-311.

13. Rex AP, Preus M. A diagnostic index for down syndrome. J Pediatr 1982;100:903-6.

14. Tolksdorf M, Wiedermann HR. Clinical aspects of Down's syndrome from infancy to adult life. Kiel: Springer-Verlag, 1981; 3-31.

15. Hook EB. Exclusion of chromosomal mosaicism: Tables of $90 \%, 95 \%$, and $99 \%$ confidence limits and comments on use. Am J Hum Genet 1997;29:94-7.

16. Jones KJ. Fetal alcohol syndrome. Pediatr in review 1986;8:122-7.

17. Naussbaum RL, McInnes RR, Willard HE. Thompson \& Thompson genetics in medicine. Philadelphia: WB
Saunders Co, 2001; 135-55.

18. Jenkins TM, Wapner RJ. First trimester prenatal diagnosis: Chorionic villus sampling. Semin Perinatol 1999;23:403-13.

19. Mansfield ES. Diagnosis of Down syndrome and other aneuploidies using quantitative polymerase chain reaction and small tandem repeat polymorphisms. Hum Molec Gen 1993;2:43-50.

20. Pertl B, Kopp S, Kroisel PM, Tului L, Brambati B, Adinolfi M. Rapid detection of chromosome aneuploidies by quantitative fluorescence PCR: first application on 247 chorionic villus samples. J Med Genet 1999;36:300-3. 